\title{
Comprehensive analysis of clinical significance of stem-cell related factors in renal cell cancer
}

Yongchao Liu ${ }^{1 \dagger}$, Changcun Zhang ${ }^{1 \dagger}$, Jie Fan ${ }^{1 *}$, Lei Xiao ${ }^{2}$, Bingde Yin ${ }^{1}$, Libin Zhou ${ }^{1}$ and Shujie Xia ${ }^{1}$

\begin{abstract}
Background: C-MYC, LIN28, OCT4, KLF4, NANOG and SOX2 are stem cell related factors. We detected whether these factors express in renal cell carcinoma (RCC) tissues to study their correlations with the clinical and pathological characteristics.

Methods: The expressions of C-MYC, LIN28, SOX2, KLF4, OCT4 and NANOG in 30 RCC patients and 5 non-RCC patients were detected with quantitative real-time reverse transcription-PCR (qRT-PCR). The data were analyzed with Wilcoxon signed rank sum test and $x^{2}$ test.
\end{abstract}

Results: In RCC group, C-MYC expression was significantly higher in RCC tissues compared with normal tissues $(\mathrm{P}<$ 0.05). The expression levels of OCT4, KLF4, NANOG and SOX2 were significantly lower in RCC tissues compared with normal tissues $(P<0.05)$. LIN28 expression level was not significant. No difference was observed when it comes to clinical and pathological characteristics such as gender, age, tumor size, cTNM classification and differentiation status $(P>0.05)$. Also the expression levels of all above factors were not significantly changed in non-RCC group ( $P>0.05)$.

Conclusions: The present analysis strongly suggests that altered expression of several stem cell related factors may play different roles in RCC. C-MYC may function as an oncogene and OCT4, KLF4, NANOG and SOX2 as tumor suppressors.

Keywords: C-MYC, LIN28, KLF4, SOX2, OCT4, NANOG, Kidney Neoplasm

\section{Background}

In 2007, Takahshi et al [1] successfully demonstrated the induction of pluripotent stem cells from adult human fibroblast by transfection of four transcription factors: OCT3/4, SOX2, c-MYC and KLF4. Yu et al [2] developed a similar method to restore the pluripotency of human somatic cells by transfecting OCT4, SOX2, NANOG and LIN28. Recently, we reported that transducting adult rat cells with lentivirus containing a cocktail of reprogramming factors of OCT4, SOX2, c-MYC and KLF4 could create rat pluripotent stem cell lines, rather than using lentivirus containing OCT4, SOX2, NANOG and LIN28 genes [3]. Besides the potential to induce the pluripotency, more studies are reported on cancer stem cells because of their functions to regulate the proliferation, differentiation

\footnotetext{
* Correspondence: jief67@sina.com

† Contributed equally

'Department of Urology, Shanghai First People's Hospital, School of

Medicine, Shanghai Jiaotong University, Shanghai 200080, China

Full list of author information is available at the end of the article
}

and metastasis [4-10]. Bussolati et al [11] found tumorinitiating stem cells in human RCC; however, few studies combined all these stem cell related factors together in pathological specimens of RCC. RCC has increased over the last decades [12]. Our previous study on stem cells [3] triggered us to clarify the correlation between the clinical characteristics and the expressions of c-MYC, LIN28, KLF4, SOX2, OCT4 and NANOG in RCC, and thereby to evaluate their existence and roles in RCC.

\section{Methods}

\section{Clinical samples of renal cell cancer}

Totally, we collected the specimens of 35 patients after nephrectomy from December 2007 to October 2010 in Shanghai First People's Hospital. The specimens were collected from normal region (outside the range of tumor or nidus at least $5 \mathrm{~cm}$ macroscopically) and tumor/nidus for each patient. The case matched paired specimens were classified into the RCC group and non-RCC group

\section{Biomed Central}


according to the pathological examination. Finally 30 paired specimens identified as 28 clear cell carcinomas, 1 papillary carcinoma and 1 chromophobe renal carcinoma, were included in the RCC group, and 5 identified as 2 urothelial transitional cell cancer, 1 renal harmatoma, 1 renal tuberculosis and 1 benign tumor in the non-RCC group. In the RCC group there were 18 male patients and 12 female patients, with an average age of 60 (40 to 84). Of them 13 were classified as stage I, 13 as stage II, 4 as stage III in accordance with cTNM of AJCC (American Joint Committee on Cancer), whereas 6 as grade I, 15 as grade II and 9 as grade III according to their differentiation status. There were 4 female patients and 1 male patient in non-RCC group with the average age of 55.4 (44 to 68). Two patients diagnosed as urothelial neoplasms were classified as stage III and stage IV respectively according to cTNM classification and both of them were in grade I according to their differentiation status. All the specimens were kept at $-80{ }^{\circ} \mathrm{C}$ immediately after surgery until RNA extraction. All patients were informed and consent. The tissue specimens were confirmed by a pathologist.

\section{Total RNA extraction, reverse transcription and qRT-PCR}

Total RNA from tissues was extracted using TRizol reagent (Invitrogen, CA, cat.no: 15596-018). Briefly, total RNA was extracted from frozen tissues. The tissue was first ground into powder in mortar with continuous flow of liquid nitrogen to prevent the tissue from thawing. About 50-100 mg of the powder was homogenized in $1 \mathrm{~mL}$ TRizol reagent. The mixture was kept on ice for $5 \mathrm{~min}$. After centrifuging at $16,200 \times \mathrm{g}$ at $4^{\circ} \mathrm{C}$ for $15 \mathrm{~min}$, the supernatant was transferred into another RNase-free tube along with $0.2 \mathrm{~mL}$ chloroform. The tube was shaken vigorously for $15 \mathrm{sec}$ and kept on ice for $10 \mathrm{~min}$. After centrifuging at $16,200 \times \mathrm{g}$ at $4^{\circ} \mathrm{C}$ for $15 \mathrm{~min}$, the supernatant was transferred into another tube with $0.5 \mathrm{~mL}$ isopropanol, blended and kept on ice for $5 \mathrm{~min}$. After centrifuging at $16,200 \times \mathrm{g}$ for $15 \mathrm{~min} \mathrm{~g}$ at $4^{\circ} \mathrm{C}$ for $10 \mathrm{~min}$, the supernatant was discarded and the precipitate was washed with $75 \%$ ethanol at $4{ }^{\circ} \mathrm{C}$. After centrifuging at $5,600 \times \mathrm{g}$ at $4^{\circ} \mathrm{C}$ for $6 \mathrm{~min}$, the supernatant was discarded and the residue was air dried at room temperature. The RNA pellet was suspended with diethyl pyrocarbonate treated water at $55^{\circ} \mathrm{C}$ for $10 \mathrm{~min}$.

RNA quantity and quality were determined by agarose gel electrophoresis and spectrophotometer at $260 \mathrm{~nm}$.

Reverse transcription for mRNAs was performed using the PrimeScriptTM RT reagent kit (TaKaRa, Dalian, China, cat.no: DRR037A). The cDNA template was amplified by real-time PCR using the SYBR ${ }^{\circledR}$ Premix EX TaqTM II kit (TaKaRa, Dalian, China, cat.no: DRR081A). Thermal cycling conditions were as follows: $95^{\circ} \mathrm{C}$ for $60 \mathrm{sec}$ followed by 35 cycles of $94^{\circ} \mathrm{C}$ for $10 \mathrm{sec}, 59^{\circ} \mathrm{C}$ for
$30 \mathrm{sec}$ and $72^{\circ} \mathrm{C}$ for $30 \mathrm{sec}$. After amplification, products were subjected to $60^{\circ} \mathrm{C}$ to $95^{\circ} \mathrm{C}$, reading plate every $0.4^{\circ} \mathrm{C}$ and holding for $1 \mathrm{sec}$ to create a melting curve. Glyceraldehyde-3-phosphate-dehydrogenase (GAPDH) mRNA was used as an internal control to normalize target mRNA level. PCR products were determined by electrophoresis on $1 \%$ agarose gels containing ethidium bromide.

Primer sequences are as follow: c-myc-forward, 5'ACAGCTACGGAACTCTTGTGCGTA-3', reverse, 5'GCCCAAAGTCCAATTTGAGGCAGT-3'; LIN28, forward 5'- GAAGAAGAAATCCACAGCCCTAC-3', reverse 5'- GATGGTGTGAACCCAAGCCTG-3'; SOX2, forward 5'- CCCATGCACCGCTACGACGTG-3', reverse 5'GCTGGAGCTGGCCTCGGACTT-3'; KLF4, forward 5'GAAATTCGCCCGCTCAGATGAACT-3', reverse 5'TCTTCATGTGTAAGGCGAGGTGGT -3'; OCT4, forward 5' - TCCCATGCATTCAAACTGAGGTGC-3', reverse 5' - AACTTCACCTTCCCTCCAACCAGT-3'; NANOG, forward 5'- CCCAAAGGCAAACAACCCACTTCT-3', reverse 5' - AGCTGGGTGGAAGAGAACACAGTT-3'. GAPDH was used as an internal control with the following primers: forward 5'- TCGACAGTCAGCCGCATCTTCTTT -3', reverse 5'- ACCAAATC CGTTGACTCCGACCTT-3'.

The relative expression fold change of microRNAs and target mRNAs were calculated by the $2^{-\Delta \Delta C t}$ method [13]. All reactions were performed in triplicate.

\section{Statistical Analysis}

All tests were analyzed by SAS 8.0 with Wilcoxon signed rank sum test and $\mathrm{x}^{2}$ test. $\mathrm{P}$-value $<0.05$ was considered to be statistically significant.

\section{Results}

\section{Deregulation of C-MYC, LIN28, OCT4, KLF4, NANOG and} SOX2

qRT-PCR analysis demonstrated that in the RCC group the expressions of stem cell related factors except LIN28 in cancer tissues were significantly changed comparing with normal tissues $(\mathrm{P}<0.05)($ Table 1$)$. C-MYC was significantly up-regulated and KLF4, SOX2, OCT4, and NANOG were significantly down-regulated (Table 1 ). However, the expressions showed no significance in the non-RCC group (data not shown).

\section{The association between expression level with clinical and pathological characteristics}

We analyzed the data to see if any correlation exists between the stem cell related factors and clinical characteristics. No expression significance of each stem-cell related factor in gender, age and tumor size was observed between RCC and non-RCC group (Table 2, 3).

As for the pathological characteristics such as cTNM classification and the differentiation status of cancers, 
Table 1 Significances of deregulated stem cell related factors

\begin{tabular}{llll}
\hline names & No of down regulated & No of up regulated & P value \\
\hline C-MYC & 8 & 22 & 0.0010 \\
LIN28 & 15 & 15 & 0.6083 \\
KLF4 & 25 & 5 & 0.0050 \\
SOX2 & 28 & 2 & $<0.0001$ \\
OCT4 & 26 & 4 & 0.0070 \\
NANOG & 29 & 1 & $<0.0001$ \\
\hline
\end{tabular}

The data were from RCC group. In each paired case matched specimens (cancer and normal tissue from the same patient), the expression level of cancer comparing with normal tissue more than 1 is considered up regulated, or it is down regulated. All experiments are performed three times. P value $<0.05$ was considered statistically significant

the expression levels of c-MYC, LIN28, KLF4, SOX2, OCT4 and NANOG were not significant either( Table $2,3)$

\section{Discussion}

Although the number of the RCC cases was limited in our study, the results are still with interesting implications. First, in the RCC group the over expression of c-MYC in cancers was significantly higher than that of normal tissues (Table 1). No difference of c-MYC was observed in the non-RCC group. This is in accordance

Table 2 The expression levels of stem cell related factors in terms of clinical and pathological characteristics

\begin{tabular}{|c|c|c|c|c|c|c|c|c|c|c|c|c|c|}
\hline \multirow[t]{2}{*}{ Items } & \multirow[t]{2}{*}{$\begin{array}{l}\text { No of } \\
\text { cases }\end{array}$} & \multicolumn{2}{|c|}{$\begin{array}{c}\text { C- } \\
\text { MYC }\end{array}$} & \multicolumn{2}{|c|}{ LIN28 } & \multicolumn{2}{|c|}{ KLF4 } & \multicolumn{2}{|c|}{ SOX2 } & \multicolumn{2}{|c|}{ OCT4 } & \multicolumn{2}{|c|}{ NANOG } \\
\hline & & $\uparrow$ & $\downarrow$ & $\uparrow$ & $\downarrow$ & $\uparrow$ & $\downarrow$ & $\uparrow$ & $\downarrow$ & $\uparrow$ & $\downarrow$ & $\uparrow$ & $\downarrow$ \\
\hline \multicolumn{14}{|l|}{ Gender } \\
\hline Male & 18 & 11 & 7 & 11 & 7 & 3 & 15 & 2 & 16 & 3 & 15 & 1 & 17 \\
\hline Female & 12 & 11 & 1 & 4 & 8 & 2 & 10 & 0 & 12 & 1 & 11 & 0 & 12 \\
\hline \multicolumn{14}{|l|}{$\begin{array}{l}\text { Age } \\
\text { (years) }\end{array}$} \\
\hline$\leq 65$ & 22 & 17 & 5 & 12 & 10 & 4 & 18 & 2 & 20 & 4 & 18 & 1 & 21 \\
\hline$>65$ & 8 & 5 & 3 & 3 & 5 & 1 & 7 & 0 & 8 & 0 & 8 & 0 & 8 \\
\hline \multicolumn{14}{|c|}{ Tumor size $(\mathrm{cm})$} \\
\hline$\leq 4$ & 12 & 9 & 3 & 7 & 5 & 3 & 9 & 1 & 11 & 3 & 9 & 1 & 11 \\
\hline$>4$ & 18 & 13 & 5 & 8 & 10 & 2 & 16 & 1 & 17 & 1 & 17 & 0 & 18 \\
\hline \multicolumn{14}{|l|}{ cTNM } \\
\hline I & 13 & 10 & 3 & 8 & 5 & 2 & 11 & 1 & 12 & 2 & 11 & 1 & 12 \\
\hline II & 13 & 9 & 4 & 6 & 7 & 2 & 11 & 1 & 12 & 1 & 12 & 0 & 13 \\
\hline III & 4 & 3 & 1 & 1 & 3 & 1 & 3 & 0 & 4 & 1 & 3 & 0 & 4 \\
\hline \multicolumn{14}{|c|}{ Differentiation } \\
\hline Well & 6 & 5 & 1 & 3 & 3 & 1 & 5 & 0 & 6 & 0 & 6 & 0 & 6 \\
\hline Moderate & 15 & 12 & 3 & 7 & 8 & 3 & 12 & 2 & 13 & 2 & 13 & 1 & 14 \\
\hline Poor & 9 & 5 & 4 & 5 & 4 & 1 & 8 & 0 & 9 & 2 & 7 & 0 & 9 \\
\hline
\end{tabular}

The data were from RCC group. $\uparrow$ represent in each paired case matched specimens (cancer and normal tissue from the same patient), the expression level of cancer comparing with normal tissue is more than 1, or it is down regulated and it is represented by $\downarrow$. All experiments are performed three times.
Table 3 Significances of deregulated stem cell related factors in terms of clinical and pathological characteristics

\begin{tabular}{lccccc}
\hline Items & \multicolumn{5}{c}{ P value } \\
\cline { 2 - 6 } & Gender & Age & Tumor size & cTNM & Differentiation \\
\hline C-MYC & 0.0683 & 0.4263 & 0.8684 & 0.8141 & 0.2020 \\
LIN28 & 0.1427 & 0.4169 & 0.4637 & 0.1936 & 0.7976 \\
KLF4 & 1.0000 & 0.7166 & 0.3255 & 0.7272 & 0.7308 \\
SOX2 & 0.2399 & 0.3855 & 0.7689 & 0.6767 & 0.8371 \\
OCT4 & 0.5178 & 0.2028 & 0.1313 & 0.8784 & 0.2274 \\
NANOG & 0.4142 & 0.5465 & 0.2207 & 0.3106 & 0.8864 \\
\hline
\end{tabular}

The data were from RCC group. Expression levels were combined with clinical and pathological characteristics with Wilcoxon signed rank sum test and $\mathrm{x}^{2}$ test. $\mathrm{P}$ value $<0.05$ was considered statistically significant.

with Tang's report [4], and c-MYC is an oncogene associated with RCC growth and proliferation by up regulating target genes like BCL2, CCND1, PCNA, PGK1 and VEGFA. C-MYC could also induce a somatic cell to regain pluripotency together with OCT4, SOX2 and KLF4 [1]. In addition, c-MYC can activate the transcription of hTERT that can regulate the activation of telomerase [14]. These all indicate that c-MYC plays an important role in RCC.

Interestingly an important regulatory network involving c-MYC, let-7 and LIN28/L28b was found recently $[6,15,15-23]$. There is a double-negative-feedback loop between LIN28/IN28b and let-7 where let-7 is able to repress LIN28/LIN28b by binding to the 3'UTR of LIN28/ LIN28b transcripts and LIN28/LIN28b can also repress let-7 [15-17]. Another feedback loop is between LIN28 and c-MYC: LIN28/LIN28b up regulates c-MYC by repressing let-7 [6] and c-MYC transcriptionally activates both LIN28 and LIN28b [18]. Also, c-MYC is one of the targets of let-7 [19-21]; in return let-7 can be repressed by MYC contributing to tumorigeness [22,23]. Besides let-7, derepression of c-MYC might also contribute to the repression and activation of diverse miRNAs related to tumorigeness [22]. The whole regulatory circuits may contribute to the widespread deregulation of miRNAs in many human malignancies [24]. Although the expression of LIN28 was not significantly different between normal specimens and tumors and we see no expression difference of LIN-28 in non-RCC group either (Table 1), we think that we need to do more to explore the function of LIN28/let-7/c-MYC regulatory circle in RCC.

KLF4 is a member of Kruppel like factors, which has a dual function related to the tumorigeness [25]. KLF4 plays as a tumor suppressor in gastric cancer, colon cancer, esophagus cancer, bladder cancer, lung cancer and pancreatic ductal carcinoma [7,26-28]. Our study shows that the expression of KLF4 in cancers was significantly lower than that in normal tissues (Table 1). This suggests that KLF4 may function as a tumor suppressor in RCC. 
$\mathrm{Lu}$ [10] reported that SOX2 was over-expressed in human squamous cell lung tumors and some adenocarcinomas. Sanada et al [29] saw an increasing expression of SOX2 with the progression of pancreatic carcinoma. In our study, SOX2 was lower in cancers compared with normal tissues. Its expression level was significantly down regulated in RCC (Table 1). Given that some biomarker like KLF4 mentioned above may function totally reversely in different cancers [25], we think it is possible that SOX2 may be a tumor suppressor in RCC.

OCT4 is essential to reprogram somatic ells to regain pluripotency [30]. Looijenga [31] found that OCT4 is positive in RCC, but its expression is quite low comparing with germ cell tumor. So it is in accordance with the theory that the amount of cancer stem cell is quite small in tumor and even less in solid tumor [32,33]. As for NANOG, Yu [2] achieved a significant breakthrough in reprogramming somatic cells back to pluripotent stem cells. As reported by Ezeh [8] and Hart [9], NANOG expressed in embryonal carcinomas, seminomas and breast cancer, and could be a valuable marker of tumorigeness. According to the report of Bussolati et al [11], the RCC stem cells they identified were OCT4 and NANOG sharply positive, but we saw some interesting results about the above-mentioned two factors, they both were significantly down regulated in RCC (Table 1). Also we did not see any significant correlation between their expression and clinical and pathological characteristics (Table 2,3). We thought there were several reasons contributing to this. First, OCT4 and NANOG are not specific biomarkers for RCC or they do not play dominant roles in the tumorigeness of RCC, but according to Bussolati's [11] report, OCT4 and NANOG are expressed in tumor-initiating CD105+ stem cells in human renal carcinomas. Cells from CD105+ clones cultured in epithelial or endothelial differentiating medium for 2 weeks acquired the expression of differentiative markers and lost stem cell markers. So this may not be the main reason for our result. Second, most cells in cancer are subgroups of cancer stem cells which only express a narrow range of stem cell related factors. So only a tiny part of these cells can present the whole characters of stem cell. Last but not the least, the cancer stem cell is really rare in the tumor as mentioned previously [32,33]. Also, OCT4 and NANOG might function as tumor suppressors in RCC indeed. We think Bussolati's [11] positive findings of OCT4 and NANOG in RCC stem cells is because that they isolated CD105+ cells from other ones just like a kind of purification. According to Moreira's [34] report, in lung cancers, stem cell markers are expressed with different patterns seen for different histological types and degrees of differentiation, considering that our RCC specimens were restricted to clear cell RCC (28 in 30), we still cannot eliminate OCT4 and NANOG as non-potential biomarkers for RCC and more comprehensive studies are needed to elucidate their importance.

Although all stem cell related factors except LIN28 were significantly deregulated (Table 1 ), there were no significant results in terms of clinical and pathological characteristics (Table 2,3). There are some reasons contributing to this. Fist, we think that if cancer stem cells do exist in RCC, they could just initiate the carcinogenesis progress, and were not dependable after initiation. Second, our patient number is limited and we don't have follow-up information. Like Zhang's [35] report about OCT4 in lung adenocarcinoma, there were no significant findings in terms of clinical and pathological characteristics, but when they combined OCT4 expression level with the follow-up information of 5 years, OCT4 was found to be the independent prognostic factor. So this may be one of drawbacks in our study. But our study first combined all the six stem cell related factors with tissue specimens. This will provide us with useful information to explore more about the function of the six stem cell related factors in RCC.

\section{Conclusions}

In conclusion, the results of our analysis of stem cell related factors between RCC and non-RCC groups, suggest that deregulation of these factors may be one of the oncogenic mechanisms underlying RCC pathogenesis. Especially, the expression of c-MYC, KLF4, OCT4, NANOG and SOX2 implies that these 5 factors are involved in carcinogenesis and progression of RCC, and probably there are RCC cancer stem cells existing in renal carcinoma. More data are needed to confirm our hypothesis.

\section{Abbreviations}

RCC: renal cell carcinoma; qRT-PCR: quantitative real-time reverse transcription-PCR; GAPDH: glyceraldehyde-3-phosphate-dehydrogenase.

\section{Acknowledgements}

This work was supported by the following grants and foundations: Innovation Program of Shanghai Municipal Education Commission (Grant No: 09ZZ25) and Program of Science and Technology Commission of Shanghai Municipality (Grant No: 09411968100). We will appreciate Ren Jiangtao, Cheng Lu and Hong Yan for their help in our experiments.

\section{Author details}

${ }^{1}$ Department of Urology, Shanghai First People's Hospital, School of Medicine, Shanghai Jiaotong University, Shanghai 200080, China. 'Laboratory of Molecular Cell Biology, Institute of Biochemistry and Cell Biology, Cell Bank, Stem Cell Bank, Shanghai Institutes for Biological Sciences, Chinese Academy of Sciences, Shanghai 200031, China.

\section{Authors' contributions}

$Y L$ and $C Z$ carried out all the experimental studies. $Y L$ drafted the manuscript and performed the statistical analysis. BY and LZ collected all specimens. JF conceived of the study and participated in its design and coordination. JF, LX and SX helped to draft the manuscript. All authors read and approved the final manuscript.

\section{Competing interests}

The authors declare that they have no competing interests. 
Received: 27 July 2011 Accepted: 7 October 2011

Published: 7 October 2011

\section{References}

1. Takahashi K, Tanabe K, Ohnuki M, Narita M, Ichisaka T, Tomoda K, Yamanaka S: Induction of pluripotent stem cells from adult human fibroblasts by defined factors. Cell 2007, 131:861-872.

2. Yu J, Vodyanik MA, Smuga-Otto K, Antosiewicz-Bourget J, Frane JL, Tian S, Nie J, Jonsdottir GA, Ruotti V, Stewart R, et al: Induced pluripotent stem cell lines derived from human somatic cells. Science 2007, 318:1917-1920.

3. Liao J, Cui C, Chen S, Ren J, Chen J, Gao Y, Li H, Jia N, Cheng L, Xiao H, Xiao $L$ : Generation of induced pluripotent stem cell lines from adult rat cells. Cell Stem Cell 2009, 4:11-15.

4. Tang SW, Chang WH, Su YC, Chen YC, Lai YH, Wu PT, Hsu Cl, Lin WC, Lai MK, Lin JY: MYC pathway is activated in clear cell renal cell carcinoma and essential for proliferation of clear cell renal cell carcinoma cells. Cancer Lett 2009, 273:35-43.

5. Guo Y, Chen Y, Ito H, Watanabe A, Ge X, Kodama T, Aburatani H: Identification and characterization of lin-28 homolog B (LIN28B) in human hepatocellular carcinoma. Gene 2006, 384:51-61.

6. Viswanathan SR, Powers JT, Einhorn W, Hoshida Y, Ng TL, Toffanin S, O'Sullivan M, Lu J, Phillips LA, Lockhart VL, et al: Lin28 promotes transformation and is associated with advanced human malignancies. Nat Genet 2009, 41:843-848.

7. McConnell BB, Ghaleb AM, Nandan MO, Yang WW: The diverse functions of Kruppel-like factors 4 and 5 in epithelial biology and pathobiology. Bioessays 2007, 29:549-557.

8. Ezeh UI, Turek PJ, Reijo RA, Clark AT: Human embryonic stem cell genes OCT4, NANOG, STELLAR, and GDF3 are expressed in both seminoma and breast carcinoma. Cancer 2005, 104:2255-2265.

9. Hart AH, Hartley L, Parker K, Ibrahim M, Looijenga LH, Pauchnik M, Chow CW, Robb L: The pluripotency homeobox gene NANOG is expressed in human germ cell tumors. Cancer 2005, 104:2092-2098.

10. Lu Y, Futtner C, Rock JR, Xu X, Whitworth W, Hogan BL, Onaitis MW: Evidence that SOX2 overexpression is oncogenic in the lung. PLoS One 2010, 5:e11022.

11. Bussolati B, Bruno S, Grange C, Ferrando U, Camussi G: Identification of a tumor-initiating stem cell population in human renal carcinomas. Faseb $J$ 2008, 22:3696-3705.

12. Hollingsworth JM, Miller DC, Daignault S, Hollenbeck BK: Rising incidence of small renal masses: a need to reassess treatment effect. J Natl Cancer Inst 2006, 98:1331-1334.

13. Livak K, Schmittgen TD: Analysis of relative gene expression data using real-time quantitative PCR and the 2(-Delta Delta C(T)) Method. Methods 2001, 25:402-408.

14. Liu X, Dakic A, Chen R, Disbrow GL, Zhang Y, Dai Y, Schlegel R: Cellrestricted immortalization by human papillomavirus correlates with telomerase activation and engagement of the hTERT promoter by Myc. J Virol 2008, 82:11568-11576.

15. Bussing I, Slack FJ, Grosshans H: let-7 microRNAs in development, stem cells and cancer. Trends Mol Med 2008, 14:400-409.

16. Piskounova E, Viswanathan SR, Janas M, LaPierre RJ, Daley GQ, Sliz P, Gregory Rl: Determinants of microRNA processing inhibition by the developmentally regulated RNA-binding protein Lin28. I Biol Chem 2008, 283:21310-21314.

17. Rybak A, Fuchs H, Smirnova L, Brandt C, Pohl EE, Nitsch R, Wulczyn FG: A feedback loop comprising lin-28 and let-7 controls pre-let-7 maturation during neural stem-cell commitment. Nat Cell Biol 2008, 10:987-993.

18. Viswanathan SR, Daley GQ: Lin28: A microRNA regulator with a macro role. Cell 2010, 140:445-449.

19. Kumar MS, Lu J, Mercer KL, Golub TR, Jacks T: Impaired microRNA processing enhances cellular transformation and tumorigenesis. Nat Genet 2007, 39:673-677.

20. He XY, Chen JX, Zhang Z, Li CL, Peng QL, Peng HM: The let-7a microRNA protects from growth of lung carcinoma by suppression of $\mathrm{k}$-Ras and cMyc in nude mice. J Cancer Res Clin Oncol 2009, 136:1023-1028.

21. Wong TS, Man OY, Tsang CM, Tsao SW, Tsang RK, Chan JY, Ho WK, Wei WI, To VS: MicroRNA let-7 suppresses nasopharyngeal carcinoma cells proliferation through downregulating c-Myc expression. I Cancer Res Clin Oncol 2011, 137:415-422.
22. Chang TC, Yu D, Lee YS, Wentzel EA, Arking DE, West KM, Dang CV, Thomas-Tikhonenko A, Mendell JT: Widespread microRNA repression by Myc contributes to tumorigenesis. Nat Genet 2008, 40:43-50.

23. Sampson VB, Rong NH, Han J, Yang Q, Aris V, Soteropoulos P, Petrelli NJ, Dunn SP, Krueger L: MicroRNA let-7a down-regulates MYC and reverts MYC-induced growth in Burkitt lymphoma cells. Cancer Res 2007, 67:9762-9770.

24. Lu J, Getz G, Miska EA, Alvarez-Saavedra E, Lamb J, Peck D, SweetCordero A, Ebert BL, Mak RH, Ferrando AA, et al: MicroRNA expression profiles classify human cancers. Nature 2005, 435:834-838.

25. Foster KW, Liu Z, Nail CD, Li X, Fitzgerald TJ, Bailey SK, Frost AR, Louro ID, Townes TM, Paterson AJ, et al: Induction of KLF4 in basal keratinocytes blocks the proliferation-differentiation switch and initiates squamous epithelial dysplasia. Oncogene 2005, 24:1491-1500.

26. Evans PM, Liu C: Roles of Krupel-like factor 4 in normal homeostasis, cancer and stem cells. Acta Biochim Biophys Sin (Shanghai) 2008, 40:554-564.

27. Zhou Y, Hofstetter WL, He Y, Hu W, Pataer A, Wang L, Wang J, Yu L, Fang B, Swisher SG: KLF4 inhibition of lung cancer cell invasion by suppression of SPARC expression. Cancer Biol Ther 2010, 9:507-513.

28. Zammarchi F, Morelli M, Menicagli M, Di Cristofano C, Zavaglia K, Paolucci A, Campani D, Aretini P, Boggi U, Mosca F, et al: KLF4 is a novel candidate tumor suppressor gene in pancreatic ductal carcinoma. Am J Pathol 2011, 178:361-372.

29. Sanada Y, Yoshida K, Ohara M, Oeda M, Konishi K, Tsutani Y: Histopathologic evaluation of stepwise progression of pancreatic carcinoma with immunohistochemical analysis of gastric epithelial transcription factor SOX2: comparison of expression patterns between invasive components and cancerous or nonneoplastic intraductal components. Pancreas 2006, 32:164-170.

30. Jaenisch R, Young R: Stem cells, the molecular circuitry of pluripotency and nuclear reprogramming. Cell 2008, 132:567-582.

31. Looijenga LH, Stoop H, de Leeuw HP, de Gouveia Brazao CA, Gillis AJ, van Roozendaal KE, van Zoelen EJ, Weber RF, Wolffenbuttel KP, van Dekken $H$ et al: POU5F1 (OCT3/4) identifies cells with pluripotent potential in human germ cell tumors. Cancer Res 2003, 63:2244-2250.

32. Bonnet $\mathrm{D}$, Dick JE: Human acute myeloid leukemia is organized as a hierarchy that originates from a primitive hematopoietic cell. Nat Med 1997, 3:730-737.

33. Reya T, Morrison SJ, Clarke MF, Weissman IL: Stem cells, cancer, and cancer stem cells. Nature 2001, 414:105-111.

34. Moreira AL, Gonen M, Rekhtman N, Downey RJ: Progenitor stem cell marker expression by pulmonary carcinomas. Mod Pathol 2010, 23:889-895.

35. Zhang X, Han B, Huang J, Zheng B, Geng Q, Aziz F, Dong Q: Prognostic significance of OCT4 expression in adenocarcinoma of the lung. Jpn $J$ Clin Oncol 2010, 40:961-966.

doi:10.1186/1477-7819-9-121

Cite this article as: Liu et al: Comprehensive analysis of clinical significance of stem-cell related factors in renal cell cancer. World Journal of Surgical Oncology 2011 9:121.

\section{Submit your next manuscript to BioMed Central and take full advantage of:}

- Convenient online submission

- Thorough peer review

- No space constraints or color figure charges

- Immediate publication on acceptance

- Inclusion in PubMed, CAS, Scopus and Google Scholar

- Research which is freely available for redistribution 